\title{
Assessing the bird guild patterns in heterogeneous land use types around Jammu, Jammu and Kashmir, India
}

\author{
Asha Sohil and Neeraj Sharma* (D)
}

\begin{abstract}
Land-use sprawl in the Himalayas has caused the conversion of natural habitat into human-modified habitats, thus degrading ecosystem health. Adaptation of birds to changing physical environment can be well understood by analyzing their habitat preferences, and foraging dynamics explored to a limited extent in the Himalayan region, as yet. To achieve a comprehensive understanding of avian guild structure, we used multivariate statistical techniques to classify bird species according to their similarities in foraging patterns and habitat preferences. Observations based on habitat and diet affinities accounted for rich avian diversity with a total of 208 bird species (about 15\% of country's avifauna) recorded from six different sites during 1 year survey. Unweighted pair-group average cluster analysis performed on the families revealed ten feeding and fifteen habitat guilds among 63 bird families observed. Subtropical forests harbored more species followed by urban forests and agricultural landscapes. Insectivorous and omnivorous outnumbered other feeding guilds in the study area. Bird assemblages were richer in protected areas and semidisturbed landscapes and did not show significant variation between the seasons. Results of the study revealed that different functional groups of birds behaved differently, primarily induced by choice of food. The site heterogeneity favored avifaunal persistence by providing favorable foraging, roosting, and nesting opportunities to birds. Composition of avian guilds indicated level of intactness and ecological integrity of ecosystems studied. This outcome thus sets the background for long-term analysis of bird-habitat relationship and their foraging dynamics. The study has the relevance for decision-makers to integrate avian guild structure as an essential ingredient in formulating conservation strategies.
\end{abstract}

Keywords: Avian guild, Food resource utilization, Habitat preference, Heterogeneous landscape, Eutrophic wetland, Protected area

\section{Introduction}

Identification and analysis of ecological guilds have been fundamental to understand processes that determine the structure and organization of communities (González-Salazar et al. 2014; Kornan and Kropil 2014), and each species fulfills the ecological role according to its use of resources within a community (Ricklefs 2010). The best measure to understand bird community structure is to classify them into feeding guilds and habitat guilds (Thiollay 1995; Clough et al. 2009). Guilds are regulated by the food supply, vegetative cover,

\footnotetext{
*Correspondence: nirazsharma@gmail.com

Institute of Mountain Environment, University of Jammu, Jammu, India
}

predators, and various other ecological factors reflecting temporal variations and diversity gradients (O'Connell 2000; Kissling et al. 2012; Katuwal et al. 2016). Application and utilization of guilds have been widely discussed in animal ecology (Blaum et al. 2011) and extensively studied in birds, among the other taxonomic groups (Sabo and Holmes 1983; Recher et al. 1985; Chettri et al. 2005; Perez-Crespo et al. 2013; González-Salazar et al. 2014; Koli 2014; Mukhopadhyay and Mazumdar 2019). Birds are potential predictors of the integrity and function of habitats (Mukhopadhyay and Mazumdar 2019), ecosystem health, and stress (MacArthur and MacArthur 1961; Taper et al. 1995), richness and

\section{Springer Open}

(C) The Author(s). 2020 Open Access This article is licensed under a Creative Commons Attribution 4.0 International License, which permits use, sharing, adaptation, distribution and reproduction in any medium or format, as long as you give appropriate credit to the original author(s) and the source, provide a link to the Creative Commons licence, and indicate if changes were made. The images or other third party material in this article are included in the article's Creative Commons licence, unless indicated otherwise in a credit line to the material. If material is not included in the article's Creative Commons licence and your intended use is not permitted by statutory regulation or exceeds the permitted use, you will need to obtain permission directly from the copyright holder. To view a copy of this licence, visit http://creativecommons.org/licenses/by/4.0/. 
conservation significance (Pearman 2002; Bensizerara et al. 2013). Bird species composition and guild structure vary spatially (Holmes et al. 1979; Holmes and Recher 1986) as they prefer to live in heterogeneous landscapes to best suit their nesting, perching, roosting, and foraging (Berg 2002; Aggarwal et al. 2008; Veech et al. 2011). The food availability and pattern of food exploitation (Rosenberg 1990; Albrecht and Gotelli 2001; Palmer et al. 2003) in a particular habitat determine bird distributions (Evans and Dugan 1984) and community structure (Gotelli and Colwell 2011; Bonilla et al. 2012). Knowledge of resource utilization (MacNally 1983; Winemiller and Pianka 1990; Bell 2001; Kattan and Franco 2004; López de Casenave et al. 2008) and assessment of foraging guilds and habitat preferences of avian species are vital to analyzing their responses to changing habitats and their conservation policies (Lawton et al. 1998; Sekercioglu 2006). Moreover, the association of birds with their habitats helps to decipher the influence of biotic interactions on bird species distributions (Jankowski et al. 2013).

Studies indicate that bird-habitat selection and its use is mainly governed by landscape structure (Fairbanks 2004; Titeux et al. 2004; Oja et al. 2005; Borges et al. 2017; Mahiga et al. 2019), food competition and availability (Petit and Petit 1996; Chatterjee and Basu 2017), variable climate and human activities (Davis et al. 2000). As different bird guilds respond differently to such changes (Barragan et al. 2011; Phalan et al. 2011; Newbold et al. 2014a), an understanding of such responses is essential to depict their resilience to the changing land use patterns (Chatterjee and Basu 2017). Man-altered environment influences bird communities in positive or negative ways depending on the biology of each functional group (Clough et al. 2009). A major threat to the persistence of birds is human-induced habitat loss and fragmentation driven by urbanization (Isaksson 2018). While several other species fail to persist in fragmented urban landscapes, the birds, because of their mobility and plasticity, have been successful at exploiting the urban habitats (Pennington and Blair 2012). Urban terrestrial bird communities colonize heterogeneous patches of crop fields, woodlands, wetlands, grasslands, and farms with suitable resources for their survival needs (Veech et al. 2011; Berg 2002). Aquatic bird communities with specialized habitat and foraging requirements (Andradea et al. 2018) are structurally more complex in interactions (Albrecht and Gotelli 2001; Palmer et al. 2003) and resource partitioning (López de Casenave et al. 2008). The forest specialists rely on the vegetation type and structure (Gabbe et al. 2002; Earnst and Holmes 2012) as a substrate for food and shelter (Lee and Rotenberry 2005). Generalists are particularly favored during the process of recolonization (Newbold et al. 2014b), while the specialists, being sensitive, become more prone to extinction in forest fragments (Henle et al. 2004).
The Northwestern Himalaya in the Indian Himalayan Region known for distinct physiography, climatic variability, and rich biodiversity (Kumar 2018) constitutes one of the significant ecological amplitudes in the world (Korner 2000; Myers et al. 2000). Erstwhile state of Jammu and Kashmir, home to 555 bird species (Suhail et al. 2020) forms a critical Endemic Bird Area (EBA 128) with 11 restricted-range species (Stattersfield et al. 1998). Status and number of bird species, birding hotspots, and their conservation ranking are currently under revision for the newly carved Union Territory of Jammu and Kashmir (India Code 2020), comprising the current study area. While the valley of Kashmir is home to many residents and migratory birds (Rahmani et al. 2016), the Jammu region holds a rich avifaunal diversity as well (Sharma et al. 2018; Sohil and Sharma 2019; Sohil and Sharma 2020). Though birds have primarily been surveyed for richness, diversity, and distribution (Pandotra and Sahi 2014; Sohil and Sharma 2019; Sohil and Sharma 2020), information on their guild structure and functions is scanty for the region. Intensive surveys were undertaken to enable understanding of habitat preferences and foraging dynamics of birds in mosaic landscapes around Jammu. This study focused on a central question: what are the foraging habits and habitat use of bird assemblages in different sites around Jammu, Jammu and Kashmir? For this study, we hypothesized that (a) bird assemblages vary in terms of their habitat and foraging preferences among different sites in a subtropical region, and (b) habitat choices of birds corresponded to their food preferences.

\section{Materials and methods}

\section{Study area}

The study was conducted in six different sites with varied physiography in urban-suburban-farmland landscapes around Jammu city $\left(32^{\circ} 34^{\prime} 29^{\prime \prime} \mathrm{N}\right.$ to $32^{\circ} 45^{\prime} 08^{\prime \prime}$ $\mathrm{N}$ and $74^{\circ} 40^{\prime} 06^{\prime \prime} \mathrm{E}$ to $74^{\circ} 53^{\prime} 29^{\prime \prime}$ E, elevation 260 $470 \mathrm{~m}$ above msl) (Table 1, Fig. 1). Study sites included two aquatic (a) a distributary of river Tawi (Nikki Tawi, NT), and (b) a small eutrophic wetland (Gharana Wetland Conservation Reserve, GWCR) and four terrestrial habitats (c) a protected area (Ramnagar Wildlife Sanctuary, RWLS), (d) reserve forest (Bahu-Mahamaya Forest, BMF), (e) University of Jammu Campus (JU), and (f) suburban landscape comprised of agriculture and fallow land (Southern Open Plains, SOP) (Table 1). Study area is characterized by a typical subtropical climate with four distinct seasons, spring (February-March), summer (April-June), monsoon (July-September), and winter (November-January). The maximum summer temperature ranges between 36 and $42^{\circ} \mathrm{C}$ and average 
Table 1 Characteristic features of sampling sites with details on geo-features, sampling size, and the level of disturbances

\begin{tabular}{|c|c|c|c|c|c|c|c|c|}
\hline $\begin{array}{l}\text { Study } \\
\text { Site }\end{array}$ & $\begin{array}{l}\text { Location } \\
\text { (acronym) }\end{array}$ & Lat/long & $\begin{array}{l}\text { Grid size } \\
\left(\mathrm{km}^{2}\right)\end{array}$ & $\begin{array}{l}\text { Elevation } \\
\text { ( } \mathrm{m} \text { above } \mathrm{ms} l)\end{array}$ & Site description & $\begin{array}{l}\text { Level of } \\
\text { disturbance }\end{array}$ & $\begin{array}{l}\text { Transects/PCS } \\
\text { no./rad./length }\end{array}$ & $\begin{array}{l}\text { Hours spent/ } \\
\text { fortnight }\end{array}$ \\
\hline 1 & $\begin{array}{l}\text { Nikki Tawi } \\
(\mathrm{NT})\end{array}$ & $\begin{array}{l}32^{\circ} 43^{\prime} \\
14^{\prime \prime} \mathrm{N} \\
74^{\circ} 50^{\prime} \\
17^{\prime \prime} \mathrm{E}\end{array}$ & 4 & $290-300$ & $\begin{array}{l}\text { A natural distributary of river Tawi bifurcated } \\
\text { close to fourth Tawi bridge southwards of } \\
\text { Jammu City with high municipal waste load } \\
\text { (Sohil and Sharma 2020) }\end{array}$ & High & $\begin{array}{l}\text { PCS-05 } \\
\left(25 m R^{*} 5\right)\end{array}$ & 6.5 \\
\hline 2 & $\begin{array}{l}\text { Gharana } \\
\text { Wetland } \\
\text { Conservation } \\
\text { Reserve } \\
\text { (GWCR) }\end{array}$ & $\begin{array}{l}32^{\circ} 34^{\prime} \\
29^{\prime \prime} \mathrm{N} \\
74^{\circ} 40^{\prime} \\
06^{\prime \prime} \mathrm{E}\end{array}$ & 1 & 262 & $\begin{array}{l}\text { A small eutrophic wetland (185 acres), a } \\
\text { designated Important Bird Area (IBA) is } \\
\text { home to a number of trans-boundary win- } \\
\text { ter visitors }\end{array}$ & Moderate & $\begin{array}{l}\text { PCS-04 } \\
(25 \mathrm{~m} \mathrm{R} * 4)\end{array}$ & 7.0 \\
\hline 3 & $\begin{array}{l}\text { University of } \\
\text { Jammu } \\
\text { campus (JU) }\end{array}$ & $\begin{array}{l}32^{\circ} 43^{\prime} \\
08^{\prime \prime} \mathrm{N} \\
74^{\circ} 51^{\prime} \\
58^{\prime \prime} \mathrm{E}\end{array}$ & 2 & $320-335$ & $\begin{array}{l}\text { Sprawled in } 118 \text { acres, the campus provides } \\
\text { a rich array of bird refuges in the form of } \\
\text { lawns, plantations, and hedges with well- } \\
\text { maintained botanical and cactus gardens }\end{array}$ & Moderate & $\begin{array}{l}\text { LT-05 } \\
(100 m * 5)\end{array}$ & 7.5 \\
\hline 4 & $\begin{array}{l}\text { Ramnagar } \\
\text { Wildlife } \\
\text { Sanctuary } \\
\text { (RWLS) }\end{array}$ & $\begin{array}{l}32^{\circ} 45^{\prime} \\
08^{\prime \prime} \mathrm{N} \\
74^{\circ} 52^{\prime} \\
15^{\prime \prime} \mathrm{E}\end{array}$ & 5 & $360-450$ & $\begin{array}{l}\text { A well-managed protected area }\left(31 \mathrm{~km}^{2}\right) \\
\text { with intact deciduous forests offers a rich } \\
\text { habitat to number of forest specialists }\end{array}$ & Low & $\begin{array}{l}\text { LT-03 }\left(100 m^{*} 2\right. \\
\left.\text { and } 300 m^{* 1}\right)\end{array}$ & 8.0 \\
\hline 5 & $\begin{array}{l}\text { Bahu- } \\
\text { Mahamaya } \\
\text { forest (BMF) }\end{array}$ & $\begin{array}{l}32^{\circ} 43^{\prime} \\
43^{\prime \prime} \mathrm{N} \\
74^{\circ} 53^{\prime} \\
29^{\prime \prime} \mathrm{E}\end{array}$ & 4 & $350-470$ & $\begin{array}{l}\text { A typical subtropical mixed patch of } \\
\text { deciduous forest (and exotic plantations), } \\
\text { along the left bank of river Tawi is a } \\
\text { favored bird's destination }\end{array}$ & Low & $\begin{array}{l}\text { LT-03 }\left(500 \mathrm{~m}^{*} 1\right. \\
\left.\text { and } 250 \mathrm{~m}^{*} 2\right)\end{array}$ & 7.0 \\
\hline 6 & $\begin{array}{l}\text { Southern } \\
\text { open plains } \\
\text { (SOP) }\end{array}$ & $\begin{array}{l}32^{\circ} 45^{\prime} \\
32^{\prime \prime} \mathrm{N} \\
74^{\circ} 48^{\prime} \\
26^{\prime \prime} \mathrm{E}\end{array}$ & 4 & $260-270$ & $\begin{array}{l}\text { A mixed landscape interspersed with } \\
\text { agriculture fields, fallow lands, water bodies, } \\
\text { and habitations. An ideal habitat for the } \\
\text { generalists, aquatic dependent birds and } \\
\text { raptors }\end{array}$ & Moderate & $\begin{array}{l}\text { LT-03 } \\
\left(200 \mathrm{~m}^{*} 3\right)\end{array}$ & 8.0 \\
\hline
\end{tabular}

$P C S$ point count station ( $25 \mathrm{~m}$ radius), $L T$ line transect

annual precipitation of $\sim 1000 \mathrm{~mm}$ mostly received during monsoon season.

\section{Study design and birds surveys}

Systematic surveys were conducted in 23 sampling units considered as permanent line transects and point count stations for all six sites (Table 1). For this study, 14 linear transects of varying lengths and 9 point count stations were established based on type of habitat, terrain, and access to the site (Table 1). Point count census was performed in a 25-m radius sampling plot (Bibby et al. 2000; Sutherland 2006). All transects were walked/sampled during early morning (30 min after dawn to 10:30 am) and in the late afternoon (from 4:00 pm to 30 min before dusk), twice a month from January 2017 to December 2017, following Bibby et al. (1992) and Karanth et al. (2016). We sampled 552 points in a sampling effort of $1050 \mathrm{~h}$ (Table $1)$. Line transects and point count stations were spaced at least $200 \mathrm{~m}$ apart to ensure the interdependence between sampling points. Data were collected during summer (April-June), monsoon (July-August), post-monsoon (September-October), and winter (November-January). No observations were made during inclement weather conditions. Birds were recorded for their species, number, food preferences and type of habitat use in the field by using binoculars and spotting scopes. The images were captured using telephoto mounted digital cameras. Bird identities were established by consulting the field guides (Ali 2002; Grimmett et al. 2011) besides using call and song notes (Grimmett et al. 2013; xeno-canto 2020).

\section{Guild classification}

Based on their food preferences, bird species were categorized into mutually exclusive feeding guilds following Gray et al. (2006). These included insectivorous (species feeding on insects, earthworms, small crustaceans, arthropods, etc.), carnivorous (feeding on large animals, their dead bodies/carcasses, etc.), omnivorous (feeding both on animals and plants), granivorous (eating seeds and grains), nectarivorous (feeding on nectar), and frugivorous (fruit-eating species). Species were observed exclusively for the type of food consumed as their principal diet. Secondary online source HBW Alive (2020) was referred to ascertain their food priorities. Likewise, birds were classified into 13 principal habitat guilds corresponding to their habitat preferences limited to perching, feeding, nesting, and mating for this study. These included subtropical scrub forests, subtropical broadleaved forests, subtropical pine forests, urban forests, riverbed, fallow land, garbage dumps, aerial, carcass dump, agricultural fields, aquatic, urban buildings, and littoral zone of wetland. Notably, the foraging information and habitat preferences were used to produce the guild classification for birds. 


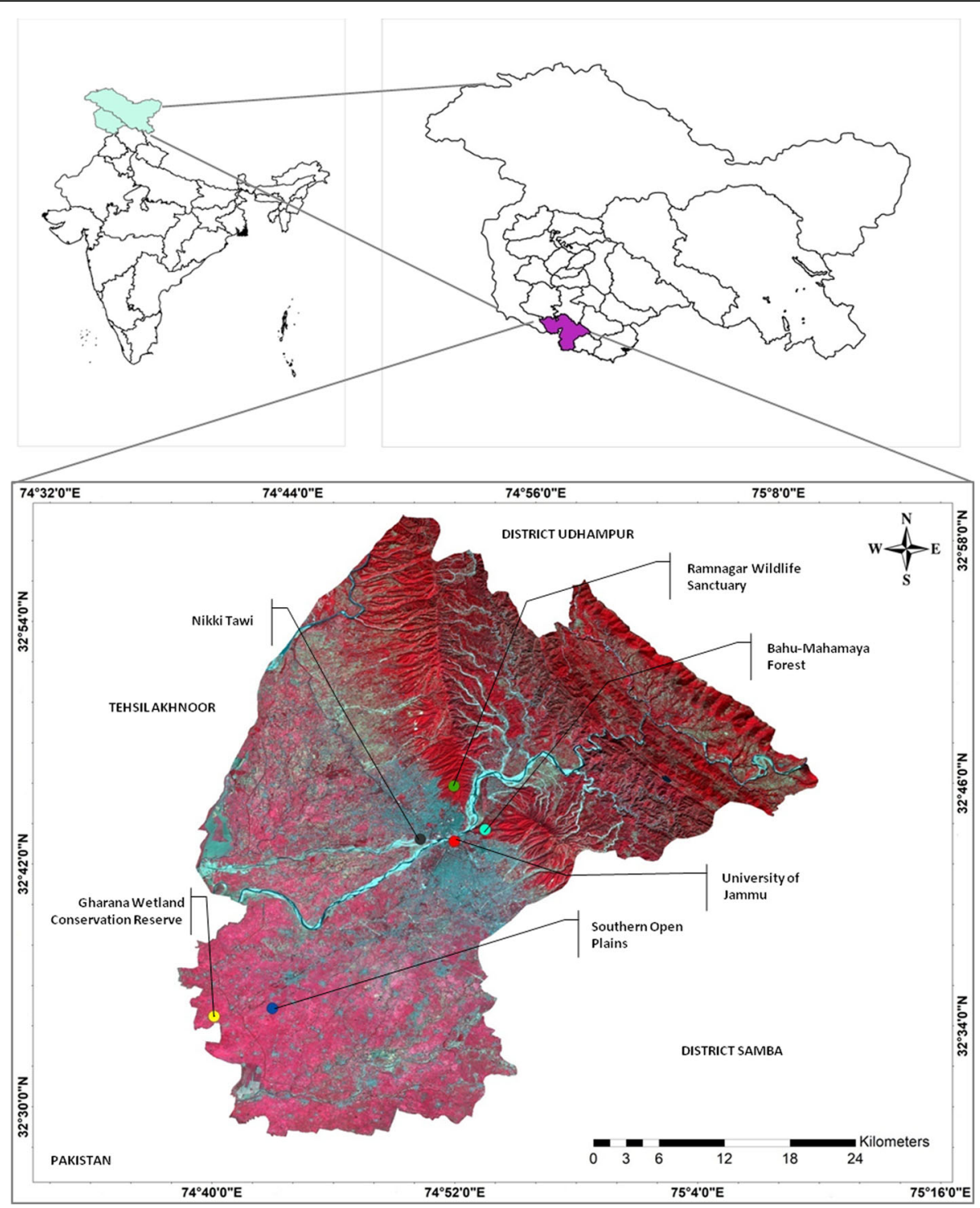

Fig. 1 Map of the study area showing sampling sites

\section{Data analysis}

Species richness was considered the pooled number of bird species occupying a particular guild. All birds observed, including the migrants, were considered for analysis as our observations were species oriented and not density driven. Feeding observations and habitat affinities noted for each bird species were consolidated family wise and then integrated into the respective guilds. We classified the bird guilds using the multivariate statistical techniques based on the shared resources (González-Salazar et al. 2014). Agglomerative hierarchical cluster (AHC) analysis was performed following Mukhopadhya and Mazumdar (2019) based on similarity matrix obtained using Jaccard's similarity coefficient (Krebs 1989;
Manly 1994) and dendrograms were constructed using unweighted pair-group average (Hammer et al. 2001) to understand the extent of similarity.

Variations in species richness among seasons were compared using one-way ANOVA followed by Tukey's multiple comparison tests. The non-normal data (Shapiro-Wilk normality test $W=0.92, \mathrm{df}=60, p<0.05$ ) was transformed to logarithmic scale $\left(\log _{10}\right)$ before analysis. An equivalent non-parametric Kruskal-Wallis test and Mann-Whitney $U$ test were applied for comparison of species richness ( $W=0.94, \mathrm{df}=72, p=0.03$ ) among the study sites. Statistical analyses were performed using SPSS-25 and PAST-4.0 (Hammer et al. 2001) software packages and significance was tested at $p=0.05$. 


\section{Results}

\section{Species richness among study sites}

Study area comprised of 208 bird species contained in 63 families and 16 orders, of which Ramnagar Wildlife Sanctuary harbored 113 bird species followed by Southern Open Plains (SOP, 109 species), Bahu-Mahamaya forest (BMF, 107 species), Gharana Wetland Conservation Reserve (GWCR, 106 species), University of Jammu Campus (JU, 98 species), and Nikki Tawi (NT, 65 species). Of all, 106 species (51\%) belonged to order Passeriformes. The mean monthly species richness among study sites was accounted high for Gharana Wetland Conservation Reserve (Fig. 2).

Kruskal-Wallis test revealed that bird species richness among distinct study sites were significantly different $(H$ $=16.28, \mathrm{df}=5, p=0.006)$. Multiple pairwise comparisons (Mann-Whitney $U$ test) showed significant variations $(p<0.05)$ for NT-JU, NT-SOP, NT-BMF, RWLSSOP, and BMF-SOP (Fig. 2). Family Muscicapidae with 17 species dominated all study sites followed by Accipitridae (12 species). Aquatic families, Anatidae and Scolopacidae (10 species each) were recorded exclusively from Gharana Wetland Conservation Reserve and Nikki Tawi. Mean species richness for different seasons was recorded high for summers and least for the monsoon. Results of one way ANOVA $(F=1.39, \mathrm{df}=3, p=0.253)$ indicated that bird species richness did not show any significant variation among the seasons (Fig. 3).

\section{Observation-based guild structure}

Birds observed during the study were placed in six diet categories. Insectivores contributed the maximum (90 species, 43.2\%) followed by omnivores (55 species, $26.4 \%$ ), carnivores (45 species, 21.6\%), and granivores (10 species, $4.8 \%$ ). Frugivores (6 species, $2.8 \%$ ) and nectarivores (2 species, $0.9 \%$ ) contributed the least. When compared site-wise, insectivores dominated the study area while carnivores were confined to aquatic ecosystems only. Omnivores, frugivores, granivores, and nectarivores occupied the terrestrial habitats (Fig. 4).

Based on the habitat preferences, birds were placed in 13 different habitat types classified as guilds. Among these, subtropical scrub (SS) recorded the highest number of species (115 species, 55.29\%) followed by urban forests (UF, 113 species, 54.33\%), subtropical broadleaved forests (BF, 104 species, 50\%), agricultural fields (AF, 63 species, 30.29\%), aquatic (AQ, 54 species, $25.96 \%$ ), riverbed (RB, 47 species, 22.60\%), subtropical pine forests (PF, 42 species, 20.19\%), wetland littoral zone (LZ, 28 species, 13.46\%), fallow land (FL, 15 species, 7.21\%), aerial (AE, 13 species, 6.25\%), garbage dump (GD, 6 species, 2.88\%), and carcass dumps (CD, 5 species, $2.40 \%)$. Raptors, mostly scavengers, occupied the last two guilds. A hierarchical cluster dendrogram of habitat guilds resulted in three clusters, one comprising forest ecosystems (SS, UF, and BF) occupied mostly by the forest specialists. Second group included mixed habitats (LZ, FL, AE, GD, CD, and UB) shared by generalists and raptors while the third group (AF, AQ, RB, and PF) supported a wide variety, including the aquatic and water-dependent birds (Fig. 5).

\section{UPGA cluster analysis of guild habit}

Family wise food preferences were derived by applying the UPGA cluster analysis (Jaksic and Medel 1990; Marti et al. 1993) based on Jaccard's similarity coefficient $\geq 0.54$ (Fig. 6). Ten feeding guilds were recognized among 63 families and 208 species indicated in roman numerals as I-nectarivorous (N), II-granivorous (G), IV-insectivorous (I), V-carnivorous (C), Group VII-omnivorous (O), and IX-frugivorous (F). Group III, VI, VIII, and X shared more than one food resources thus categorized as insectivorous-granivorous (I/G),

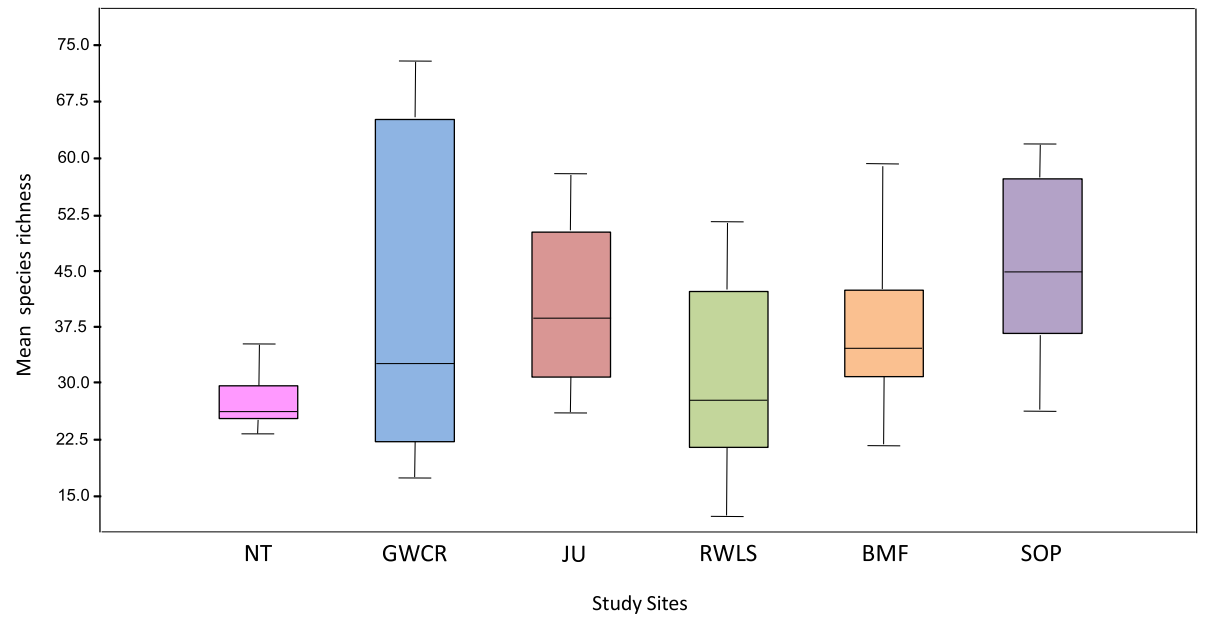

Fig. 2 Observed bird species richness across study sites during the study period 


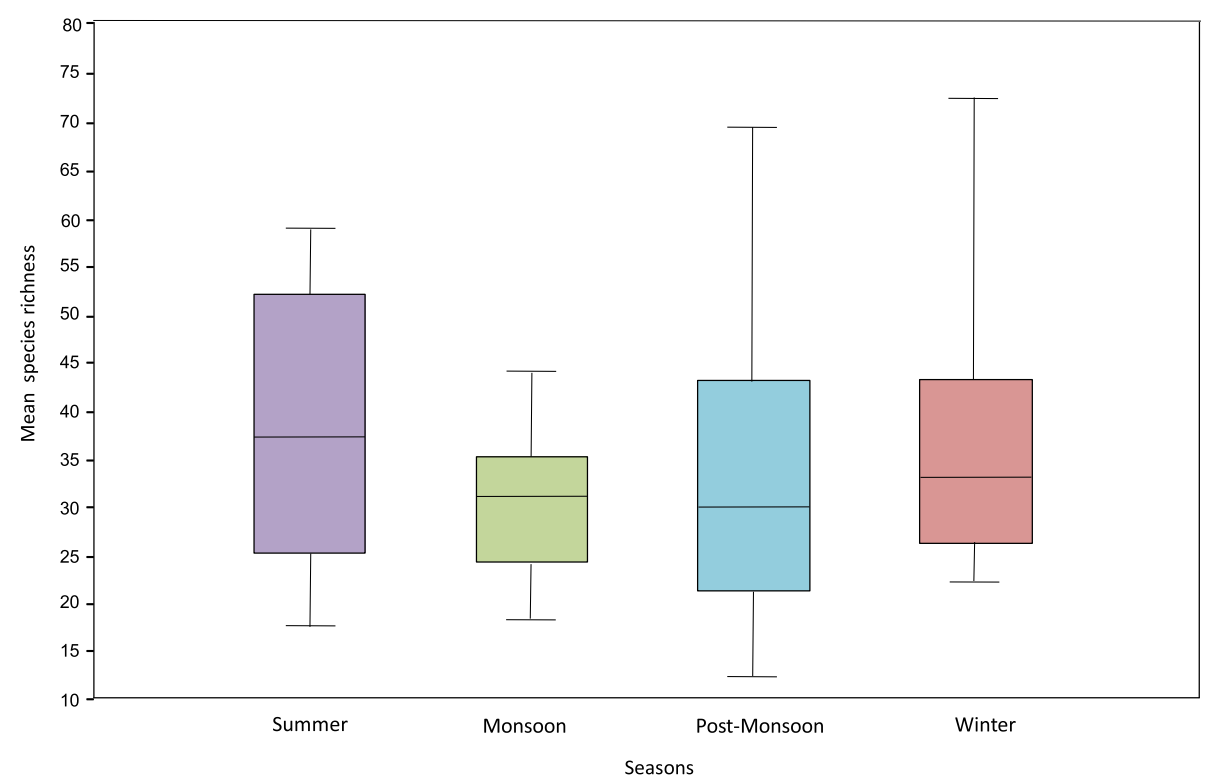

Fig. 3 Observed bird species richness across different seasons during the study period

insectivorous-carnivorous (I/C), omnivorous-carnivorous $(\mathrm{O} / \mathrm{C})$, and frugivorous-omnivorous $(\mathrm{F} / \mathrm{O})$, respectively. Each food type varied among different feeding guilds but was similar among species belonging to the same guild. Insectivores belonging to 23 avian families constituted the dominant feeding guild in the study area, followed by omnivores (16 families). Bird familial affinities in different trophic guilds are represented in Fig. 6.

Guild response of birds to the type of habitat they belong was obtained using PCA (principal component analysis). Bottom axis of PCA accounts for the dominance of carnivores in aquatic and agriculture dominated landscapes, while the top right axis portrays prevalence of omnivores and insectivores in the terrestrial ecosystems. The granivores, frugivores, and nectarivores were least represented. PCA axes I and II accounted for 92\% and $6 \%$ of the total variance, respectively (Fig. 7).

We obtained 15 habitat guilds based on the UPGA cluster analysis performed for habitat use with a mean distance of similarity $(J) \bar{x}=0.63$ (Fig. 8). Of these, guilds VIII and IX being used by 24 and 9 families were observed to be most occupied. Families Columbidae,

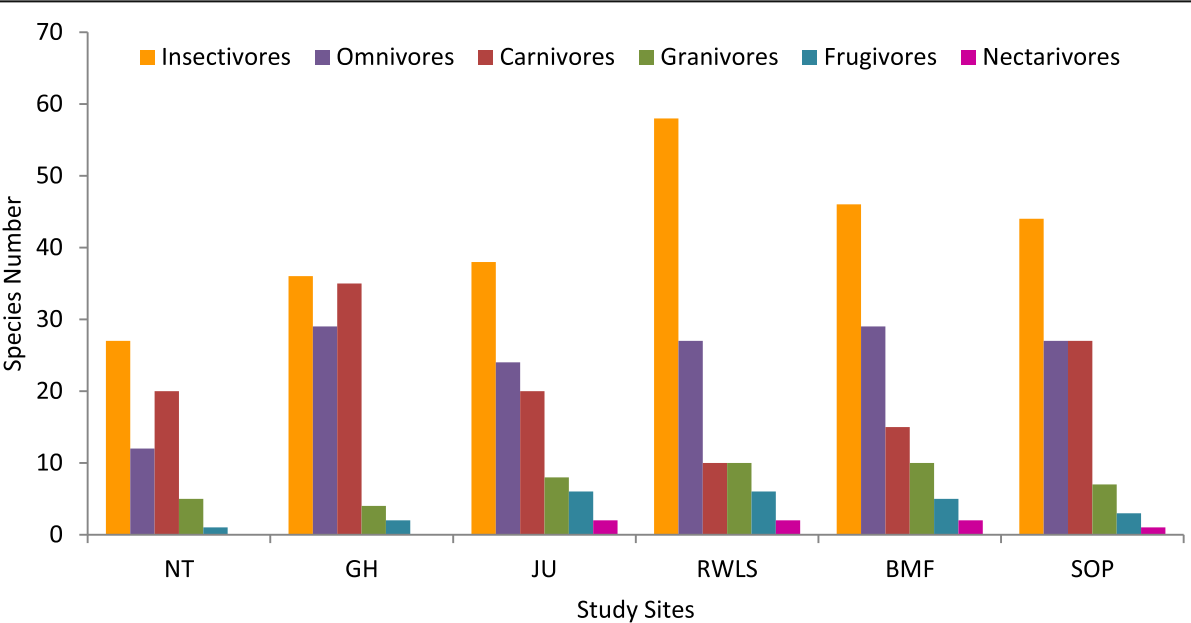

Fig. 4 Bird trophic guilds in the order of dominance. Insectivores and carnivores in aquatic (NT and GWCR); insectivores and omnivores in terrestrial (JU, RWLS, and BMF) and insectivores followed by an equal proportion of omnivores and carnivores in Southern Open Plains (SOP), the mixed ecosystem 


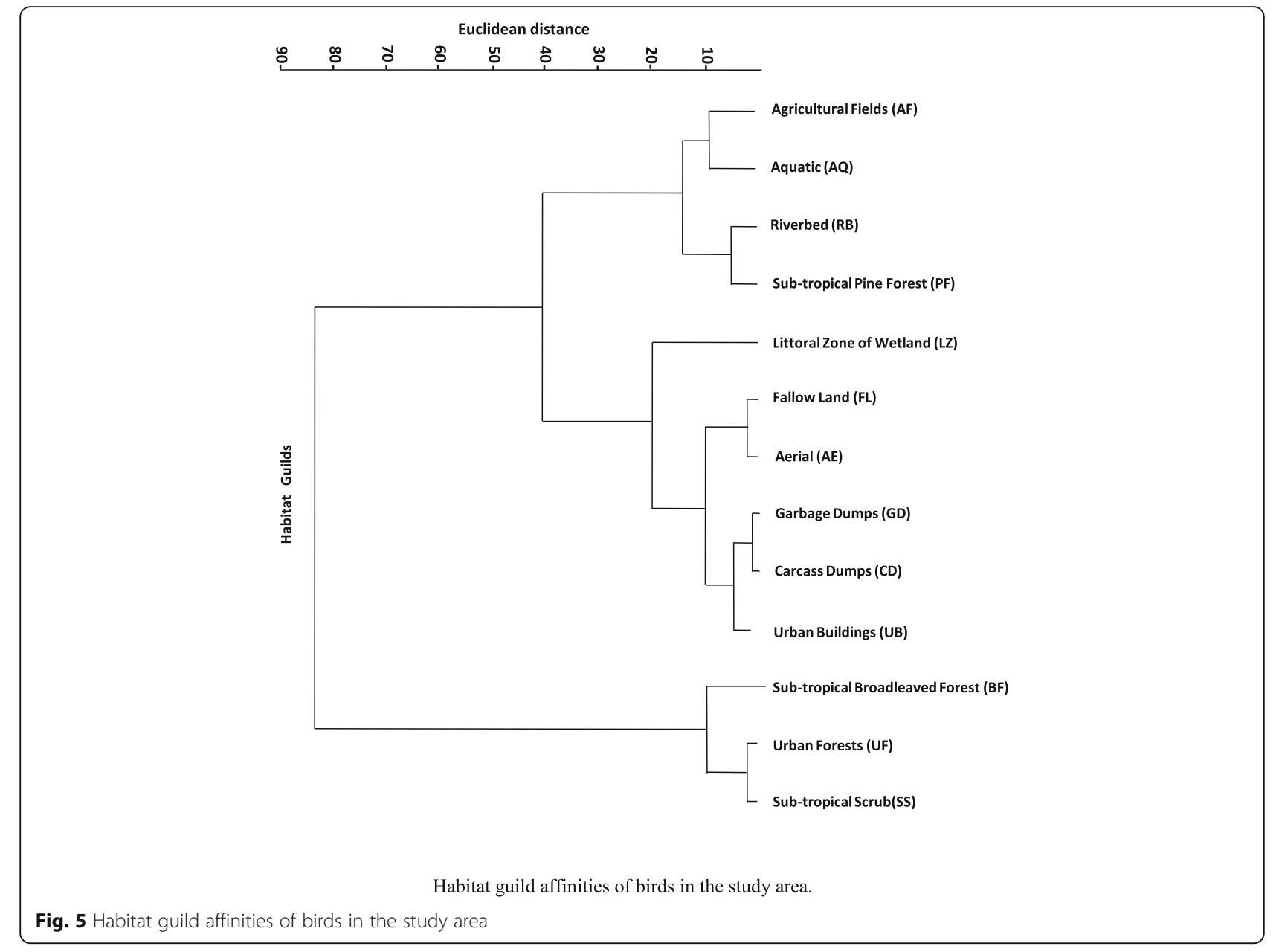

Passeridae, Hirundinidae, Corvidae, Sturnidae, Motacillidae, Muscicapidae, and Accipitridae shared diverse habitat range among others. Waterbird families, Anatidae, Ciconiidae, Gruidae, Jacanidae, Phalacocoracidae, Podicipidae, Laridae, Recurvirostridae, Scolopacidae, Rallidae, Rostratulidae, and Threskiornithidae, mostly confined around the water bodies. Members of Coracidae and Ploceidae restricted to agricultural fields and fallows. These included birds like sunbirds, swallows, martins, prinias, terns, shank, stints, sandpipers, coots, raptors, babblers, egrets, herons in guilds I, II, IV, V, VI, VII, and IX. The aquatic, semi-aquatic, farmland, and forest birds were habitat-specific (guild I, II, III, IV, X, and XV). These included shanks, stints, ducks, geese, cranes, water hens, terns, larks, cormorants, ibises, wagtails, flycatchers, thrushes, babblers, starlings, warblers, redstarts, and buntings. Generalists shared more than one guild (V, VI, VII, VIII, IX, XI, XII, XIII, and XIV). These included the species like Dicrurus macrocercus, Milvus migrans, Acridotheres tristis, Streptopelia decaocto, Merops orientalis, Pycnonotus leucogenis, Corvus splendens, Passer domesticus, Oenanthe fusca, Saxicola caprata,
Pycnonotus cafer, Columba livia, Psittacula krameri, and Streptopelia chinensis.

\section{Discussion}

Results revealed that bird assemblages are regulated by the types of habitats rather than seasons. Different functional groups behaved differently in terms of preference, mainly mediated by choice of food. Protected areas shared more guilds than disturbed landscapes. In this study, a total of 15,918 individuals of 208 bird species to 63 families were recorded from diverse habitat types around Jammu. This high species richness may be attributed to the structural complexity, and diverse habitat types as heterogeneous areas are more likely to provide shelter and refuges to birds and promote avifaunal persistence (Seto et al. 2004; Kallimanis et al. 2010; Fjeldsa et al. 2012). Species-rich Ramnagar Wildlife Sanctuary comprises a wide variety of plant assemblages and a mosaic of vegetation types that offer foraging and nesting opportunities to birds (Sohil and Sharma 2020). It corroborates a general observation that vegetation type plays a crucial role in structuring bird communities 


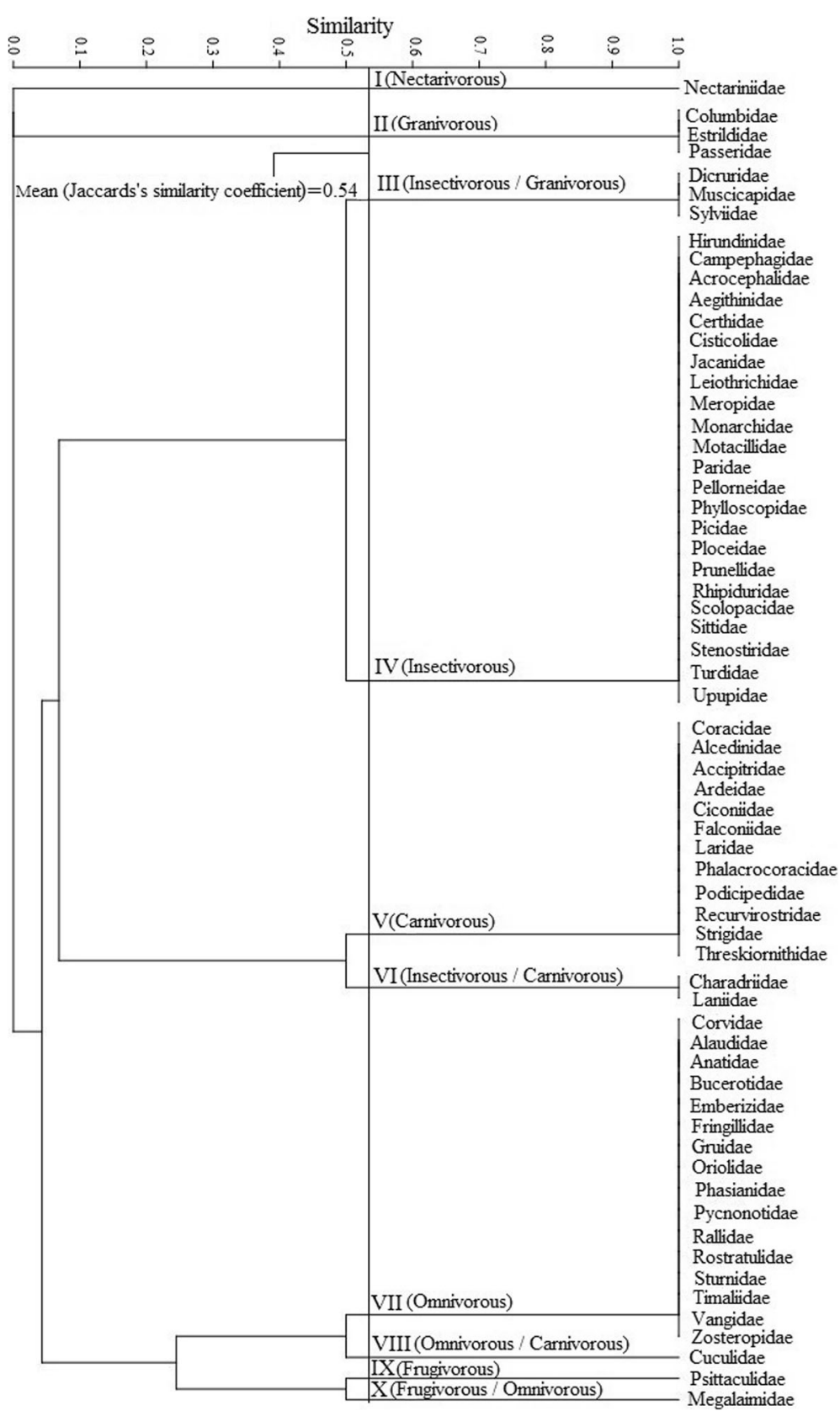

Fig. 6 Jaccard's similarity dendrogram showing foraging guild structure among observed bird families in the study area

(Earnst and Holmes 2012; Draycott et al. 2008; Tanalgo et al. 2015) and maintaining their species richness (Jokimaki and Jokimaki 2012). Mosaic landscapes (Southern Open Plains) and Gharana Wetland Conservation Reserve were reasonably rich in species while Nikki Tawi shared the least. As observed by Melles et al. (2003), Husté et al. (2006), and Shwartz et al. (2008), urbanwetland interfaces are the ideal hotspots for avian communities. The aquatic habitats have been found to support more species as resident, wetland-dependent migratory, and wetland-associated avifauna (Mazumdar et al. 2007, 2008; Mukhopadhyay and Mazumdar 2019) while forested and agriculture landscapes accommodated terrestrial birds mainly the forest specialists and birds of prey. Availability of primary requirements such as food, shelter, resting, roosting, and nesting sites that primarily influence the bird populations (Vaclav et al. 2003; Rompre et al. 2007; Zhou et al. 2007) is not equally available in all the study sites throughout different seasons (Chauhan et al. 2008; Kumar et al. 2010). Low species richness noticed during monsoon is attributed to their dispersal in search of nesting sites (Urfi 1996, 1997; Mazumdar 2019). 


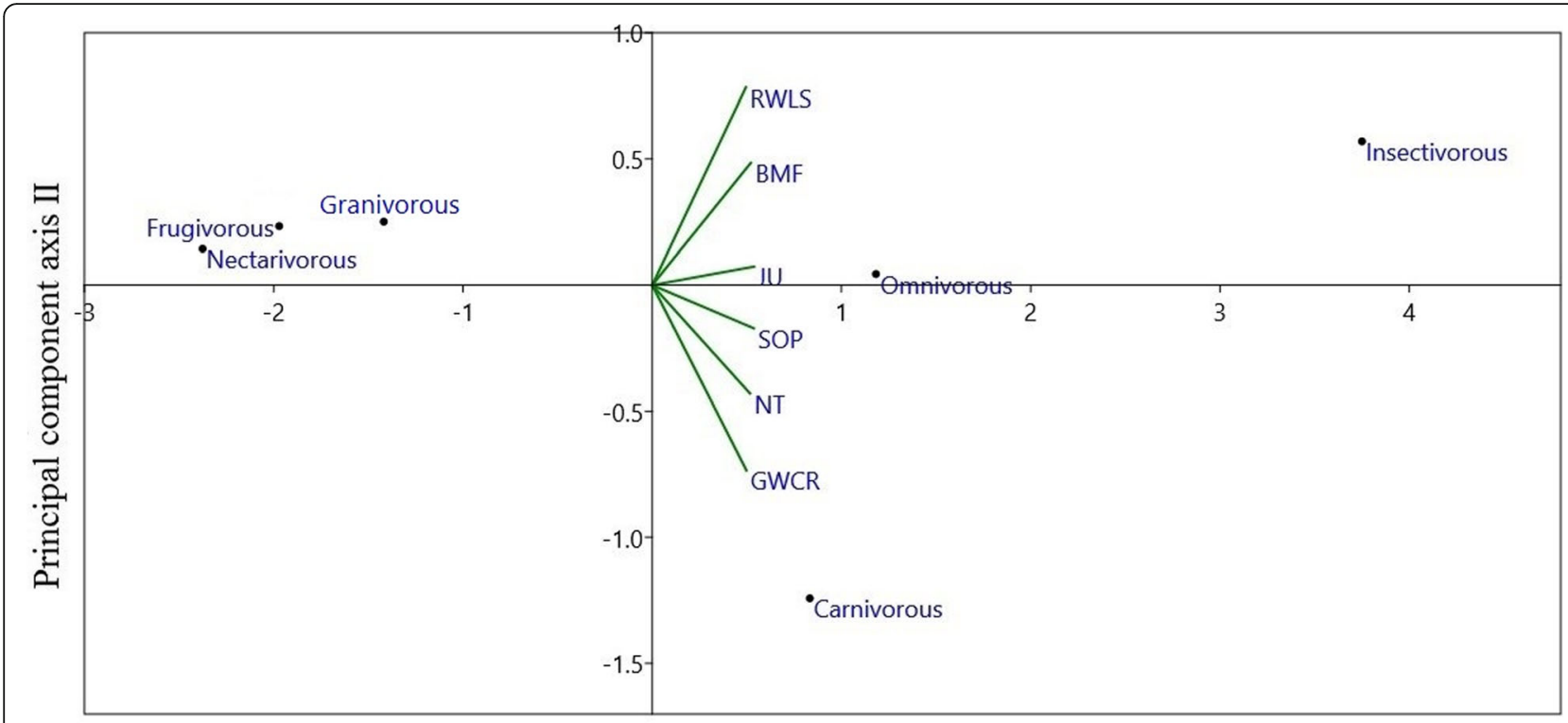

\section{Principal component axis I}

Fig. 7 Representation of bird feeding guilds corresponding to habitat types along two principal component axis among the study sites

It is well known that environmental drivers of richness vary across feeding guilds (Ding et al. 2019). Insectivores emerged as dominant feeding guild in most of the study sites followed by either omnivores or carnivores, a trend observed in several other studies from subtropical habitats (Chatterjee et al. 2013; Kottawa-Arachchi et al. 2015; Mukhopadhyay and Mazumdar 2019). Insectivores constitute most species-rich feeding guild as observed by Styringa et al. (2011), Bonilla et al. (2012), Koli (2014), Kumbar and Ghadage (2014), Ding et al. (2015), and Ding et al. (2019). These are found abundantly in insect-rich landscapes which include streamside areas, forests, and informal settlements (Gatesire et al. 2014). Increased plant productivity reflects the abundance of insects and so the abundance of insectivores (Pettorelli et al. 2011). Increase in shrub canopy in urban areas creates a suitable environment for food and shelter and enhances richness in insectivore guild (Imai and Nakashizuka 2010; Pinotti et al. 2012; Perera et al. 2017; Ferger et al. 2014). Forested landscapes and plantations around Ramnagar Wildlife Sanctuary, Bahu-Mahamaya forest, and the University of Jammu Campus offered moist conditions, high tree density, and dense foliage that harbored abundant insect fauna. Prevalence of insectivores and carnivores in aquatic habitats is attributed to an adequate food base available in nutrient-rich water of Nikki Tawi and Gharana Wetland Conservation Reserve. Santiago-Alarcon (2011), Kumar and Gupta (2013), and Whittington et al. (2013) recorded similar observations in urban aquatic ecosystems. Wetland attracts waterfowl, waders, birds of prey, and several other wetland-dependent birds year-round due to abundant food availability such as insects, crabs, shrimps, molluscs, and indigenous fish (Mukhopadhyay and Mazumdar 2019; Sohil and Sharma 2020). The vast expanse of agricultural fields dotted with villages and water bodies in southern open plains attract many species of raptors. Farmlands and water reservoirs provide enhanced food supply to raptors in the form of diverse fauna including water snakes (Tingay et al. 2010), water birds (Mukherjee and Wilske 2006), and dead fish (Sánchez-Zapata et al. 2016). The omnivore guild appeared the dominant foraging guild for terrestrial birds next to insectivores as observed by Sultana (2013), Katuwal et al. (2016), and Mukhopadhyay and Mazumdar (2019) as well. Omnivores with a tendency to exploit a wide array of natural and novel food resources (Mukhopadhyay and Mazumdar 2019) have expanded their ranges with increased abundance in urban habitats (Jokimäki and Suhonen 1993; Clergeau et al. 1998; Sorace 2002). Granivores and omnivores have higher colonization rates in agricultural degraded landscapes (Frishkoff et al. 2014) and open habitats with larger seed banks (Díaz and Telleria 1996; Chettri et al. 2005). As frugivores are regulated by fruitbearing plants (Trager and Mistry 2003; Kissling et al. 2007; Pinotti et al. 2012; Chatterjee and Basu 2015) and habitat intactness, their low numbers may be linked to less fruit plant diversity and high level of habitat fragmentation (Gomes et al. 2008). Nectarivores were related to open habitats with the prevalence of flowering plants (Laiolo 2003) strongly regulated by the blooming season (Abrahamczyk and Kessler 2010). Habitat 


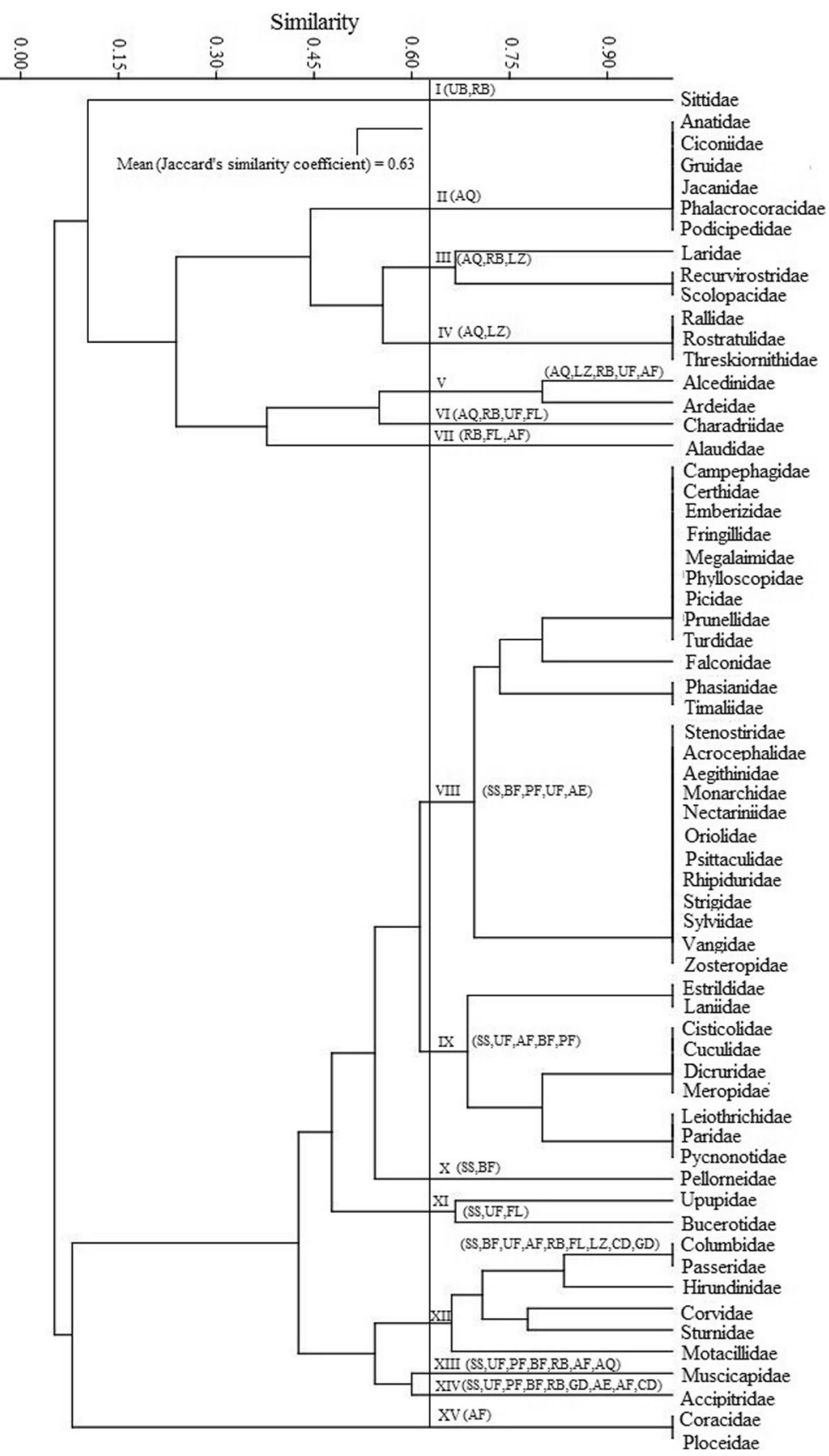

Fig. 8 Jaccard's similarity dendrogram showing habitat guild structure among observed bird families in the study area. Roman numerals refer to guilds and mnemonics in brackets represent the habitat type (see Fig. 5)

interfaces mainly harbored the carnivores comprised of raptors and a few generalists. It may be due to an increased amount of microhabitats, visibility, and prey base (Kottawa-Arachchi et al. 2012; Wijesundara and Wijesundara 2014). It can be concluded that feeding guilds with more ecological tolerance and broader resource utilization respond positively to habitat heterogeneity, whereas the specialized guilds prefer specific habitats (Bonilla et al. 2012).
Thirteen major bird habitat guilds were identified during the surveys. Most of the bird species occupied protected areas, rich in forest cover, close to urban settlements. It is established that like many other animals, birds also require a variety of habitats to live, feed, and breed (Nagy et al. 2017; Ndanganga et al. 2013; Dahal et al. 2014; Morante-Filho et al. 2015, Sharma et al. 2018). Forest type, its size, structure, and limited anthropogenic disturbance play a vital role in avifaunal 
community richness and composition (Baral and Inskipp 2005). Subtropical forests were species rich, and the protected areas, Ramnagar Wildlife Sanctuary and BahuMahamaya forest mostly harbored forest specialists. The urban forested areas attracted a large number of migratory as well as resident birds (Grimmett and Inskipp 2007; McKinney 2008; Evans et al. 2009) as the forest fragments (Donnelly and Marzluff 2004), gardens (Gaston et al. 2005; White et al. 2005), tree-lined avenues, and residential yards (Savard et al. 2000; Belaire et al. 2015; Tiwary and Urfi 2016) harbor more bird species. These natural habitats in urban matrix function as a refuge for woodland species (Croci et al. 2008), enhance the abundance of food resources, and provide nesting opportunities including cavities (Mörtberg and Wallentinus 2000). It is well known that birds form an essential part of biodiversity in urban wetlands and associated aquatic habitats (Andradea et al. 2018). Among aquatic habitats, Gharana Wetland Conservation Reserve and Nikki Tawi harbored a large number of aquatic and water-dependent birds. Wetlands provide critical foraging areas for many waterbird species (Chatterjee et al. 2020), and their high productivity enables different bird groups to use similar food resources (Weller 1999). Majority of birds observed in these wetlands were wintering visitors who are champions in resource partitioning (Polla et al. 2018). High prevalence of Anatidae and Accipitridae at Gharana Wetland Conservation Reserve indicated high ecosystem productivity and intactness (Jamwal et al. 2017). The higher number of carnivores and omnivores is attributed to the presence of a variety of aquatic invertebrates, small fishes, and aquatic plants (Sohil and Sharma 2020).

Analysis of resource utilization pattern through cluster analysis showed most of the species shared a wide range of habitat and food type. Generalists were more specious in comparison to the specialists in terms of their feeding affinities. Similar observations were recorded by PerezCrespo et al. (2013) and Chatterjee et al. (2020). The species occupying a wide array of habitats are better accustomed to habitat changes than the species confined to a few habitat types (Goerck 1997). Specialized habitats in the form of intact forest patches, ecosystem interfaces, and smaller wetlands hence call immediate conservation attention in the region. In the given findings of this study, our hypothesis holds good to be considered. The study signifies that habitat choices govern bird assemblages and their foraging preferences viz-a-viz quality and time of the year, i.e., season. Bird groups with restricted resource utilization were considered specialists.

\section{Conclusions}

It was observed that bird species responded differently to habitats in terms of choice of their food. Intact forest patches, protected areas, and wetlands with adequate food base and allied resources were species rich while the patchy landscapes were species scarce. Insectivores and omnivores emerged as the favored feeding guilds and protected areas as the preferred habitats. The findings of this study thus underline the importance of avian guild structure in regulating bird assemblages viz-a-viz their habitat improvement. The study further sets a background for intensive investigations on bird-habitat relationships, more specifically involving the species of high conservation interest. We recommend habitat conservation and improvement measures to be integrated into policy frameworks, especially those related to urban planning.

\section{Supplementary information}

Supplementary information accompanies this paper at https://doi.org/10 1186/s13717-020-00250-9.

Additional file 1. Bird species distribution (common and binomial names, familial representation), guild structure and migratory status in mosaic landscapes around Jammu.

\section{Abbreviations \\ UPGA: Unweighted pair-group average; EBA: Endemic bird area; NT: Nikki Tawi; GWCR: Gharana Wetland Conservation Reserve; RWLS: Ramnagar Wildlife Sanctuary; BMF: Bahu-Mahamaya forest; JU: University of Jammu Campus; SOP: Southern open plains; HBW: Handbook of the birds of the wild; PCA: Principal component analysis; PAST: Paleontological statistics software; SS: Subtropical scrub; BF: Subtropical broadleaved forests; PF: Subtropical pine forests; U: Urban forests; RB: Riverbed; FL: Fallow land; GD: Garbage dumps; AE: Aerial; CD: Carcass dump; AF: Agricultural fields; AQ: Aquatic; UB: Urban buildings; LZ: Littoral zone of wetland; I: Insectivorous; G: Granivorous; C: Carnivorous; O: Omnivorous; F: Frugivorous; N: Nectarivorous}

\section{Acknowledgements}

Authors thankfully acknowledge the help and support provided by Rector, Bhaderwah Campus, and Head, Department of Environmental Sciences University of Jammu. Department of Wildlife Protection, Govt. of Jammu and Kashmir is also thanked for providing necessary permissions and local logistics during the surveys. We are obliged to Bushan Kumar, Mr. Muzaffar A Kichloo, Mr. Dinesh Singh, and Ms. Vandana Dutt, the researchers in IME for their help during the field surveys. The help rendered by Drinder Singh Manhas in map synthesis is duly acknowledged.

\section{Authors' contributions}

NS conceptualized the study and edited the manuscript. AS collected and analyzed the data and wrote the manuscript. The authors read and approved the final manuscript.

\section{Funding}

The study is self-financed

Availability of data and materials

The checklist of the birds is provided as Additional file.

Ethics approval and consent to participate

All requisite information and data was collected without disturbing the birds and their habitats. Photographic records were collected using a telephoto lens. Birds in nesting were not photographed.

Consent for publication

Not applicable 


\section{Competing interests}

The authors declare that they have no competing interests.

\section{Received: 16 December 2019 Accepted: 9 August 2020} Published online: 26 September 2020

\section{References}

Abrahamczyk S, Kessler M (2010) Humming bird diversity, food niche characters, and assemblage composition along a latitudinal precipitation gradient in the Bolivian lowlands. J Ornithol 151:615-625

Aggarwal S, Sahi DN, Wani A (2008) Feeding guilds of avifauna of Nandni Wildlife Sanctuary, Jammu (Jammu and Kashmir). The Ecoscan 2:157-160

Albrecht M, Gotelli NJ (2001) Spatial and temporal niche partitioning in grassland ants. Oecologia 126:134-141

Ali S (2002) The book of Indian birds. Bombay Natural History Society, Mumbai, India

Andradea R, Batemana HL, Franklinb J, Allen D (2018) Waterbird community composition, abundance and diversity along an urban gradient. Landsc Urban Plan 170:103-111

Baral HS, Inskipp C (2005) Important bird areas in Nepal: key sites for conservation. Bird Conservation Nepal and BirdLife International, Kathmandu and Cambridge

Barragan F, Moreno CE, Escobar F, Halffte G, Navarrete D (2011) Negative impacts of human land use on dung beetle functional diversity. PLoS One 6:e17976

Belaire JA, Westphal LM, Whelan CJ, Minor ES (2015) Urban residents' perceptions of birds in the neighborhood: biodiversity, cultural ecosystem services, and disservices. Condor 117:192-202. https://doi.org/10.1650/Condor-14-128

Bell G (2001) Neutral macroecology. Science 293:2413-2418

Bensizerara D, Chenchouni H, Bachir AS, Houhamdi M (2013) Ecological status interactions for assessing bird diversity in relation to a heterogeneous landscape structure. Avian Biol Res 6:67-77

Berg A (2002) Composition and diversity of bird communities in Swedish farmland-forest mosaic landscapes. Bird Study 49:153-165. https://doi.org/10 1080/00063650209461260

Bibby CJ, Burgess ND, Hill DA (1992) Bird census techniques. Academic Press, London

Bibby CJ, Burgess ND, Hill DA, Mustoe SH (2000) Bird census techniques, 2nd edn. Academic Press, London, p 302

Blaum N, Mosner E, Schwager M, Jeltsch F (2011) How functional is functional? Ecological groupings in terrestrial animal ecology: towards an animal functional type approach. Biodivers Conserv 20:2333-2345. https://doi.org/10. 1007/s10531-011-9995-1

Bonilla EPD, León-Cortés JL, Rangel JL (2012) Diversity of bird feeding guilds in relation to habitat heterogeneity and land-use cover in a human-modified landscape in southern Mexico. J Trop Ecol 28:369-376

Borges F, Glemnitz M, Schultz A, Stachow U (2017) Assessing the habitat suitability of agricultural landscapes for characteristic breeding bird guilds using landscape metrics. Environ Monit Assess 189:166. https://doi.org/10. 1007/s10661-017-5837-2

Chatterjee S, Basu P (2015) Avian frugivory and seed dispersal of a large fruited tree in an Indian moist deciduous forest. Acta Oecol 65-66:32-40

Chatterjee S, Basu P (2017) Food preferences determine habitat selection at multiple scales: implication for bird conservation in tropical forests. Anim Conserv 21:332-342. https://doi.org/10.1111/acv.12397

Chatterjee A, Adhikari S, Barik A, Mukhopadhyay SK (2013) The mid-winter assemblage and diversity of bird populations at Patlakhawa protected forest, Coochbehar, West Bengal, India. The Ring 35. https://doi.org/10.2478/ring2013-0002

Chatterjee A, Adhikarib S, Palb S, Mukhopadhyay SB (2020) Foraging guild structure and niche characteristics of waterbirds wintering in selected subHimalayan wetlands of India. Ecol Indic 108:105693 https://doi.org/10.1016/j. ecolind.2019.105693

Chauhan RR, Shingadia HU, Sakthivel V (2008) Survey of avifauna of Borivali Mangroves along the coast of Mumbai. Nat Environ Pollut Technol 7:229-233

Chettri N, Deb DC, Sharma E, Jackson R (2005) The relationship between bird communities and habitat - a study along a trekking corridor in Sikkim Himalayas. Mt Res Dev 25:235-243

Clergeau P, Savard JPL, Mennechez G, Falardeau G (1998) Bird abundance and diversity along an urban-rural gradient: a comparative study between two cities on different continents. Condor 100:413-442
Clough Y, Dwi Putra D, Pitopang R, Tscharntke T (2009) Local and landscape factors determine functional bird diversity in Indonesian cacao agroforestry. Biol Conserv 142:1032-1041. https://doi.org/10.1016/j.biocon. 2008.12.027

Croci S, Butet A, Georges A, Aguejdad R, Clergeau P (2008) Small urban woodlands as biodiversity conservation hot-spot: a multi-taxon approach. Landsc Ecol 23:1171-1118

Dahal BR, McAlpine CA, Maron M (2014) Bird conservation values of off-reserve forests in lowland Nepal. Forest Ecol Manag 323:28-38

Davis J, Egawa R, Hall T, Haradem P, Hyman B, Judy S, Unger M (2000) Diet differentiation and habitat selection of birds in forested and clear-cut areas. Biology Department, Frostburg State University, Final Paper, pp 11

Diaz M, Telleria JL (1996) Granivorous birds in a stable and isolated open habitat within the Amazonian rainforest. J Trop Ecol 12:419-425

Ding Z, Feeley KJ, Hu H, Ding P (2015) Bird guild loss and its determinants on subtropical land-bridge islands, China. Avian Res 6:10

Ding Z, Liang J, Hu Y, Zhou Z, Sun H, Liu L, Liu H, Hu H, Si X (2019) Different responses of avian feeding guilds to spatial and environmental factors across an elevation gradient in the central Himalaya. Ecol Evol 9:4116-4128. https:// doi.org/10.1002/ece3.5040

Donnelly R, Marzluff JM (2004) Importance of reserve size and landscape context to urban bird conservation. Conserv Biol 18:733-745

Draycott RAH, Hoodless AN, Sage RB (2008) Effects of pheasant management on vegetation and birds in lowland woodlands. J Appl Ecol 45:334-341

Earnst SL, Holmes AL (2012) Bird-habitat relationships in interior Columbia basin shrub steppe. Condor 114:15-29

Evans PR, Dugan PJ (1984) Coastal birds: numbers in relation to food resources. In: Evans PR, Goss-Custard JD, Hale WG (eds) Coastal waders and wildfowl in winter. Cambridge University Press, UK, pp 8-28

Evans KL, Newson SE, Gaston KJ (2009) Habitat influences on urban avian assemblages. Ibis 151:19-39

Fairbanks DHK (2004) Regional land-use impacts affecting avian richness patterns in Southern Africa-insights from historical avian atlas data. Agric Ecosyst Environ 101:269-288

Ferger SW, Schleuning M, Hemp A, Howell KM, Bohning-Gaese K (2014) Food resources and vegetation structure mediate climatic effects on species richness of birds. Glob Ecol Biogeogr 23:541-549

Fjeldsa J, Bowie RCK, Rahbek C (2012) The role of mountain ranges in the diversification of birds. Annu Rev Ecol Evol Syst 43:249-265

Frishkoff LO, Karp DS, M'Gonigle LK, Mendenhall CD, Zook J, Kremen C, Hadly EA, Daily GC (2014) Loss of avian phylogenetic diversity in neotropical agricultural systems. Science 345:1343-1346

Gabbe AP, Robinson SK, Brawn JD (2002) Tree-species preferences of foraging insectivorous birds: implications for food plain forest restoration. Conserv Biol 16:462-470

Gaston KJ, Smith RM, Thompson K, Warren PH (2005) Urban domestic gardens: experimental tests of methods for increasing biodiversity. Biodivers Conserv 14:395-413

Gatesire T, Nsabimana D, Nyiramana A, Seburanga JL, Mirville MO (2014) Bird diversity and distribution in relation to urban landscape types in northern Rwanda. Sci World J 2014:157824

Goerck JM (1997) Patterns of rarity in the birds of the Atlantic forest of Brazil. Conserv Biol 11:112-118

Gomes LGL, Oostra V, Nijman V, Cleef AM, Kappelle M (2008) Tolerance of frugivorous birds to habitat disturbance in a tropical cloud forest. Biol Conserv 141:860-871

González-Salazar C, Martínez-Meyer E, Lopez-Santiago G (2014) A hierarchical classification of trophic guilds for North American birds and mammals. Rev Mex Biodivers 85:931-941. https://doi.org/10.7550/rmb.38023

Gotelli NJ, Colwell RK (2011) Estimating species richness. In: Magurran AE, McGill BJ (eds) Frontiers in measuring biodiversity. Oxford University Press, New York, pp 39-54

Gray MA, Baldauf SL, Mayhew PJ, Hill JK (2006) The response of avian feeding guilds to tropical forest disturbance. Conserv Biol 21:133-141

Grimmett R, Inskipp T (2007) Birds of Southern India. Om Books International, New Delhi

Grimmett R, Inskipp C, Inskipp T (2011) Birds of the Indian subcontinent. Oxford University Press, London

Grimmett R, Inskipp C, Inskipp T (2013) Birds of the Indian subcontinent: India, Pakistan, Sri Lanka, Nepal, Bhutan, Bangladesh, and the Maldives. Bloomsbury Publishing 
Hammer O, Harper DAT, Ryan PD (2001) PAST: Paleontological statistics software package for education and data analysis

Hand Book of the World Alive (2020) Lynx Edicions. Available at: http://www. hbw.com/Accessed online on 15 May 2020

Henle K, Davies KF, Kleyer M, Margules C, Settele J (2004) Predictors of species sensitivity to fragmentation. Biodiver Conserv 13:207-251. https://doi.org/10. 1023/B:BIOC.0000004319.91643.9e

Holmes RT, Recher HF (1986) Determinants of quild structure in forest bird communities: an intercontinental comparison. Condor 88:421-439

Holmes RT, Bonney RE, Pacala SW (1979) Guild structure of the Hubbard Brook bird community: a multivariate approach. Ecology 60:512-520

Husté A, Selmi S, Boulinier T (2006) Bird communities in suburban patches near Paris: determinants of local richness in a highly fragmented landscape. Écoscience 13:249-257

Imai H, Nakashizuka T (2010) Environmental factors affecting the composition and diversity of avian community in mid- to late breeding season in urban parks and green spaces. Landsc Urban Plan 96:183-194

India Code (2020) Jammu and Kashmir Reorganization Act 2019. Available at: https://indiacode.nic.in/. Accessed online on 10 May 2020

Isaksson C (2018) Impact of urbanization on birds. In: Tietze DT (ed) Bird species: how they arise, modify and vanish, fascinating life sciences. Cham: Springer International Publishing, pp 235-257. https://doi.org/10.1007/978-3-319-916 89-7_13

Jaksić FM, Medel RG (1990) Objective recognition of guilds: testing for statistically significant species clusters. Oecologia 82:87-92

Jamwal PS, Chandan P, Rattan R, Anand A, Kannan PM, Parsons MH (2017) Survey of avifauna of the Gharana wetland reserve: implications for conservation in a semi-arid agricultural setting on the contested indo-Pakistan border. BMC Zool 2:7

Jankowski JE, Merkord CL, Rios WF, Cabrera GK, Revilla NS, Silman MR (2013) The relationship of tropical bird communities to tree species composition and vegetation structure along an Andean elevational gradient. J Biogeogr 40: 950-962

Jokimaki J, Kaisanlahti-Jokimaki M (2012) The role of residential habitat type on the temporal variation of wintering bird assemblages in northern Finland. Ornis Fenn 88:20-33

Jokimaki J, Suhonen J (1993) Effects of urbanization on the breeding bird species richness in Finland: a biogeographical comparison. Ornis Fennica 70:71-77

Kallimanis AS, Bergmeier E, Panitsa M, Georghiou K, Delipetrou P, Dimopoulos P (2010) Biogeographical determinants for total and endemic species richness in a continental archipelago. Biodivers Conserv 19:1225-1235

Karanth KK, Sankararaman V, Dalvi S, Srivathsa A, Parameshwaran R, Sharma S, Robbins P, Chhatre A (2016) Producing diversity: agroforests sustain avian richness and abundance in India's Western Ghats. Front Ecol Evol 4:111 https://doi.org/10.3389/fevo.2016.00111

Kattan GH, Franco P (2004). Bird diversity along elevational gradients in the Andes of Colombia: area and mass effects. Glob Ecol Biogeogr 13:451-458. https://doi.org/10.1111/j.1466-822X.2004.00117.x

Katuwal HB, Basnet K, Khanal B, Devkota S, Rai SK, Gajurel JP, Nobis MP (2016) Seasonal changes in bird species and feeding guilds along elevational gradients of the central Himalayas, Nepal. PLoS One 11:e0158362 https://doi. org/10.1371/journal.pone.0158362

Kissling WD, Rahbek C, Böhning-Gaese K (2007) Food plant diversity as broad-scale determinant of avian frugivore richness. Proc R Soc B Biol Sci 274:799-808

Kissling WD, Sekercioglu CH, Jetz W (2012) Bird dietary guild richness across latitudes, environments and biogeographic regions. Glob. Ecol. Biogeogr 21: 328-340. https://doi.org/10.1111/j.1466-8238.2011.00679.x

Koli VK (2014) Diversity and status of avifauna in Todgarh-Raoli Wildlife Sanctuary, Rajasthan, India. J Asia Pac Biodivers 7:401-407

Kornan M, Kropil R (2014) What are ecological guilds? Dilemma of guild concepts. Russ J Ecol 45:445-447

Korner C (2000) Why are there global gradients in species richness? Mountains might hold the answer. Trends Ecol Evol 15:513-514 https://doi.org/10.1016/ S0169-5347(00)02004-8

Kottawa-Arachchi JD, Gamage RN (2015) Avifaunal diversity and bird community responses to man-made habitats in St. Coombs Tea Estate, Sri Lanka. JoTT 7: 6878-6890. https://doi.org/10.11609/JoTT.03483.6878-90

Kottawa-Arachchi JD, Gamage RN, Ariyarathne HACK, Jayathilake GG (2012) Avifaunal diversity in a tea plantation ecosystem in the up-country of Sri Lanka. In: Proceedings of International Forestry and Environment Symposium
Krebs CJ (1989) Ecological methodology. Harper and Row Publishers, New York, p 654

Kumar A (2018) Avifauna of North West Himalaya. In: Sivaperuman C, Venkataraman K (eds) Indian Hotspots vertebrate faunal diversity, conservation and management. Springer Nature Singapore Pt Ltd, India, pp 151-194

Kumar P, Gupta SK (2013) Status of wetland birds of Chhilchhila Wildlife Sanctuary, Haryana, India. JoTT 5:3969-3976. https://doi.org/10.11609/JoTT. 03158.3969-76

Kumar V, Wingfield JC, Dawson A, Remenofsky M, Rani S, Bartell P (2010) Biological clocks and regulation of seasonal reproduction and migration in birds. Physiol Biochem Zool 83:827-835

Kumbar SM, Ghadage AB (2014) Preliminary survey on avian fauna of Krishna river basin of Sangli district, western Maharashtra, India. J Environ Biol 35: 1005-1011

Laiolo P (2003) Diversity and structure of the bird community overwintering in the Himalayan sub-alpine zone: is conservation compatible with tourism? Biol Conserv 15:251-262

Lawton JH, Bignell DE, Bolton B, Bloemers GF, Eggleton P, Hammond PM, Hodda M, Holt RD, Larsen TB, Mawdsley NA, Stork NE, Srivastava DS, Watt AD (1998) Biodiversity inventories, indicator taxa and effects of habitat modification in tropical forest. Nature 391:72-76

Lee PY, Rotenberry JT (2005) Relationships between bird species and tree species assemblages in forested habitats of eastern North America. J Biogeogr 32: 1139-1150

López de Casenave J, Cueto VR, Marone L (2008) Seasonal dynamics of guild structure in a bird assemblage of the central Monte desert. Basic Appl Ecol 9: 78-90. https://doi.org/10.1016/j.baae.2006.08.006

MacArthur RH, MacArthur JW (1961) On bird species diversity. Ecology 42:594-599

MacNally RC (1983) On assessing the significance of interspecific competition to guild structure. Ecology 64:1646-1652

Mahiga SN, Webala P, Mware MJ, Ndangang PK (2019) Influence of land-use type on forest bird community composition in Mount Kenya forest. Int J Ecol 2019:8248270. https://doi.org/10.1155/2019/8248270

Manly BF (1994) Multivariate statistical methods: a primer. CRC Press, p 215

Marti CD, Steenhof K, Kochert MN, Jeffrey SM (1993) Community trophic structure: the roles of diet, body size, and activity time in vertebrate predators. Oikos 67:6-18

Mazumdar S (2019) Composition of avian communities in a human-modified wetland Okhla bird sanctuary, India: with notes on conservation initiatives. Proc Zool Soc 72 319-333 https://doi.org/10.1007/s12595-017-0239-6

Mazumdar S, Mookherjee K, Saha GK (2007) Migratory water birds of wetlands of southern West Bengal, India. Indian Birds 3:42-45

Mazumdar S, Mookherjee K, Saha GK (2008) Diversity and dominance of migratory water birds in six wetlands of southern West Bengal, India. In: Zoological research in human welfare. Zoological Survey of India, Kolkata, pp 161-166

McKinney ML (2008) Effects of urbanization on species richness: a review of plants and animals. Urban Ecosyst 11:161-176

Melles S, Glenn S, Martin K (2003) Urban bird diversity and landscape complexity: species-environment associations along a multiscale habitat gradient. Conserv Ecol 7:5-27

Morante-Filho JC, Faria D, Mariano-Neto E, Rhodes J (2015) Birds in anthropogenic landscapes: the responses of ecological groups to forest loss in the Brazilian Atlantic forest. PLoS One 10:e0128923 https://doi.org/10.1371/ journal.pone. 0128923

Mörtberg U, Wallentinus H-G (2000) Red-listed forest bird species in an urban environment - assessment of green space corridors. Landsc Urban Plan 50: 215-226

Mukherjee A, Wilske B (2006) Importance of wetlands for conservation of bird life in the dry lands of western India. In: Boere GC, Galbraith CA, Stroud DA (eds). Waterbirds around the world, the Stationary office, Edinburgh, pp 303-304

Mukhopadhyay S, Mazumdar S (2019) Habitat-wise composition and foraging guilds of avian community in a suburban landscape of lower Gangetic plains, West Bengal, India. Biologia 74:1001-1010. https://doi.org/10.2478/ s11756-019-00226-x

Myers N, Mittermeier RA, Mittermeier CG, Da Fonseca GA, Kent J (2000) Biodiversity hotspots for conservation priorities. Nature 403:853-858. https:// doi.org/10.1038/35002501

Nagy GG, Ladanyi M, Arany I, Azalos R, Czucz B (2017) Birds and plants: comparing biodiversity indicators in eight low land agricultural mosaic landscapes in Hungary. Ecol Indic 73:56-573 
Ndanganga PK, Njoroge JBM, Githiru M (2013) Vegetation composition and structure influences bird species community assemblages in the highland agricultural landscape of Nyandarua, Kenya. Ostrich 84:171-179. https://doi. org/10.2989/00306525.2013.860929

Newbold T, Scharlemann JPW, Butchart SHM, Sekercioglu CH, Joppa L, Alkemade R, Purves DW (2014a) Functional traits, land-use change and the structure of present and future bird communities in tropical forests. Global Ecol Biogeog 23:1073-1084

Newbold T, Hudson LN, Phillips HR, Hill SL, Contu S, Lysenko I, Blandon A, Butchart SHM, Booth HL, Day J, Palma AD, Harrison MLK, Kirkpatrick L, Pynegar E, Robinson A, Simpson J, Mace GM, Scharlemann JP, Purvis A (2014b) A global model of the response of tropical and sub-tropical forest biodiversity to anthropogenic pressures. Proc R Soc B-Biol Sci 281:20141371. https://doi.org/10.1098/rspb.2014.1371

O'Connell TJ, Jackson LE, Brooks RP (2000) Bird guilds as indicators of ecological conditions in the central Appalachians. Ecol Appl 10:1706-1721

Oja T, Alamets K, Parnamets H (2005) Modelling bird habitat suitability based on landscape parameters at different scales. Ecol Indic 5:314-321

Palmer TM, Stanton ML, Young TP (2003) Competition and coexistence: exploring mechanisms that restrict and maintain diversity within mutualist guilds. Am Nat 162:S63-S79

Pandotra A, Sahi DN (2014) Avifaunal assemblages in suburban habitats of Jammu, J\&K, India. Int Res J Environ Sci 3:17-24

Pearman PB (2002) The scale of community structure: habitat variation and avian guilds in tropical forest understory. Ecol Monogr 72:19-39

Pennington DN, Blair RB (2012) Using gradient analysis to uncover pattern and process in urban bird communities. In: Lepczyk CA, Warren PS (eds) Urban bird ecology and conservation: studies in avian biology. University of California Press, Berkeley, pp 9-32

Perera P, Wijesinghe S, Dayawansa N, Marasinghe S, Wickramarachchi C (2017) Response of tropical birds to habitat modifications in fragmented forest patches: a case from a tropical lowland rainforest in south-west Sri Lanka. Community Ecol 18:175-183

Perez-Crespo MJ, Fonseca J, Pineda-Lopez R, Palacios E, Lara C (2013) Foraging guild structure and niche characteristics of waterbirds in an epicontinental lake in Mexico. Zool Stud 52:1-17 http://www.zoologicalstudies.com/ content/52/1/54

Petit LJ, Petit DR (1996) Factors governing habitat selection by prothonotary warblers: field tests of the Fretwell-Lucas models. Ecol Monogr 66:367-387

Pettorelli N, Ryan S, Mueller T, Bunnefeld N, Jędrzejewska B, Lima M, Kausrud K (2011) The normalized difference vegetation index (NDVI): unforeseen successes in animal ecology. Clim Res 46:15-27. https://doi.org/10.3354/ cr00936

Phalan B, Onial M, Balmford A, Green RE (2011) Reconciling food production and biodiversity conservation: land sharing and land sparing compared. Science 333:1289-1291

Pinotti BT, Pagotto CP, Pardini R (2012) Habitat structure and food resources for wildlife across successional stages in a tropical forest. Forest Ecol Manag 283: 119-127

Polla WM, Di Pasquale V, Rasuk MC, Barberis I, Romano M, Manzo RA, Paggi JC, Farias ME, Contreras M, Devercelli M (2018) Diet and feeding selectivity of the Andean flamingo Phoenicoparrus andinus and Chilean flamingo Phoenicopterus chilensis in lowland wintering areas. Wildfowl 68:3-29

Rahmani AR, Islam MZ, Kasambe RM (2016) Important bird and biodiversity areas in India: priority sites for conservation (revised and updated). Bombay Natural History Society, Indian Bird Conservation Network, Royal Society for the Protection of Birds and BirdLife International (UK)

Recher HF, Holmes RT, Schultz M, Shields J, Kavanagh R (1985) Foraging patterns of feeding birds in eucalypt forest and woodland of southeastern Australia. Aust J Ecol 10:399-419

Ricklefs RE (2010) Evolutionary diversification, coevolution between populations and their antagonists, and the filling of niche space. Proc Natl Acad Sci USA 107(4):1265-1272

Rompre G, Robinson WD, Desrochers A, George A (2007) Environmental correlates of avian diversity in lowland Panama rain forests. J Biogeogr 34:802-815

Rosenberg KV (1990) Dead-leaf foraging specializations in tropical forest birds: measuring resource availability and use. Avian Biol Res 13:360-368

Sabo SR, Holmes RT (1983) Foraging niches and the structure of forest bird communities in contrasting montane habitats. Condor 85:121-138

Sánchez-Zapata JA, Clavero M, Carrete M, DeVault TL, Hermoso V, Losada MA, Polo MJ, Sánchez-Navarro S, Pérez-García JM, Botella F, Ibáñez C, Donázar JA
(2016) Effects of renewable energy production and infrastructure on wildlife. In: Mateo R, Arroyo B, Garcia JT(eds). Current trends in wildlife research. Springer International Publishing, pp 97-123

Santiago-Alarcon D, Arriaga-Weiss SL, Escobar O (2011) Bird community composition of centla marshes biosphere reserve, Tabasco, Mexico. Ornitol Neotrop 22:229-246

Savard JPL, Clergeau P, Mennechez G (2000) Biodiversity concepts and urban ecosystems. Landsc Urban Plan 48:131-142

Sekercioglu CH (2006) Increasing awareness of avian ecological function. Trends Ecol Evol 21:464-471. https://doi.org/10.1016/j.tree.2006.05.007

Seto KC, Fleishman E, Fay JP, Betrus CJ (2004) Linking spatial patterns of bird and butterfly species richness with Landsat TM derived NDVI. Int J Remote Sens 25:4309-4324

Sharma N, Rana SK, Raina P, Amir R, Kichloo MA (2018) An annotated checklist of the birds of upper Chenab catchment, Jammu and Kashmir, India. JoTT 10: 11869-11894

Shwartz A, Shirley S, Kark S (2008) How do habitat variability and management regime shape the spatial heterogeneity of birds within a large Mediterranean urban park. Landsc Urban Plan 84:219-229

Sohil A, Sharma N (2019) A preliminary survey of bird communities around Jammu, (Jammu \& Kashmir). Biol Forum 11:27-49

Sohil A, Sharma N (2020) Bird diversity and distribution in mosaic landscapes around Jammu, Jammu \& Kashmir. Acta Ecol Sin. https://doi.org/10.1016/j. chnaes.2020.02.005

Sorace A (2002) High density of bird and pest species in urban habitats and the role of predator abundance. Ornis Fennica 79:60-71

Stattersfield AJ, Crosby MJ, Long AJ, Wege DC (1998) Endemic bird areas of the world: priorities for biodiversity conservation. BirdLife International, Cambridge, UK

Styringa AR, Ragai R, Unggang J, Stuebing R, Hosner PA, Sheldon FH (2011) Bird community assembly in Bornean industrial tree plantations: effects of forest age and structure. Forest Ecol Manag 261:531-544

Suhail I, Ahmad R, Ahmad K (2020) Avifaunal diversity in Jammu and Kashmir State. In: Dar GH, Khuroo AA (eds). Biodiversity of the Himalaya: Jammu and Kashmir state: Topics in Biodiversity and Conservation. pp 897-931. https:// doi.org/10.1007/978-981-32-9174-4_35

Sultana A (2013) An updated checklist of birds of Sariska Tiger Reserve, Rajasthan, India. JoTT 5:4791-4804. https://doi.org/10.11609/JoTT.03215. 4791-804

Sutherland WJ (2006) Ecological census techniques: a handbook. Cambridge University Press, Cambridge, New York

Tanalgo KC, Pineda JAF, Agravante ME, Amerol ZM (2015) Bird diversity and structure in different land-use types in lowland south-central Mindanao, Philippines. Trop Life Sci Res 26:85-103

Taper ML, Bohning-Gaese K, Brown JH (1995) Individualistic responses of bird species to environmental change. Oecologia:478-486

Thiollay JM (1995) The role of traditional agroforests in the conservation of rainforest bird diversity in Sumatra. Conserv Biol 9:335-353. https://doi.org/ 10.1046/j.1523-1739.1995.9020335.x

Tingay RE, Nicoll MAC, Whitfield DP, Visal S, McLeod DRA (2010) Nesting ecology of the grey-headed fish-eagle at Prek Toal, Tonle Sap Lake, Cambodia. J Raptor Res 44:165-174

Titeux N, Dufrene M, Jacob JP, Paquay M, Defourny P (2004) Multivariate analysis of a fine-scale breeding bird atlas using a geographical information system and partial canonical correspondence analysis: environmental and spatial effects. J Biogeogr 31:1841-1856

Tiwary NK, Urfi AJ (2016) Spatial variations of bird occupancy in Delhi: the significance of woodland habitat patches in urban centres. Urban For Urban Gree 20:338-347

Trager M, Mistry S (2003) Avian community composition of kopjes in a heterogeneous landscape. Oecologia 135:458-468

Urfi AJ (1996) On some new breeding records of water birds from the Delhi region. J Bombay Nat 93:94-95

Urfi AJ (1997) The significance of Delhi Zoo for wild water birds, with special reference to painted stork Mycteria leucocephala. Forktail 12:87-98

Vaclav R, Hoi H, Blomquist D (2003) Food supplementation affects extra pair paternity in House Sparrows. Behav Ecol 14:730-735

Veech JA, Small MF, Baccus JT (2011) The effect of habitat on the range expansion of a native and an introduced bird species. J Biogeogr 38:69-77 https://doi.org/10.1111/j.1365-2699.2010.02397.x

Weller MW (1999) Wetland birds: habitat resources and conservation implications. Cambridge University Press, Cambridge, p 288 
White JG, Antos MJ, Fitzsimons JA, Palmer GC (2005) Non-uniform bird assemblages in urban environments: the influence of streetscape vegetation. Landsc Urban Plan 7:123-135

Whittington M, Malan G, Panagos MD (2013) Trends in waterbird diversity at Banzi, Shokwe and Nyamithi pans, Ndumo Game Reserve, South Africa. Ostrich 84:47-61. https://doi.org/10.2989/00306525.2013.775188

Wijesundara C, Wijesundara M (2014) Bird diversity of Dekinda Forest Reserve, Balana, Sri Lanka: implications for conservation. Ceylon J Sci 43:137-146

Winemiller KO, Pianka ER (1990) Organization in natural assemblages of desert lizards and tropical fishes. Ecol Monogr 60:27-55

xeno-canto (2020) Sharing bird sounds from around the world. Available at: https:/www.xeno-canto.org/. Accessed 10 May 2020

Zhou J, Tang L, Tang SM, Lu F, Li HM, Wu QH (2007) Impacts of landscape spatial pattern on the avian diversity in Pingyao Town, Zhejiang Province. J Fudan Univ Nat Sci 46:377-383

\section{Publisher's Note}

Springer Nature remains neutral with regard to jurisdictional claims in published maps and institutional affiliations.

\section{Submit your manuscript to a SpringerOpen ${ }^{\circ}$ journal and benefit from:}

- Convenient online submission

- Rigorous peer review

- Open access: articles freely available online

High visibility within the field

- Retaining the copyright to your article

Submit your next manuscript at $\boldsymbol{\nabla}$ springeropen.com 